\title{
THE CONCEPT OF LOCAL ECONOMIC DEVELOPMENT AND TOURISM IN THE EUROPEAN INTEGRATION PROJECT
}

\author{
Prof. Assoc. Dr. Anastazija Tanja Đelić \\ Faculty of Law, Security and Protection "Konstantin Veliki" of Niš \\ Union Nikola Tesla University Belgrade, Serbia
}

\begin{abstract}
The aim of our research is to scientifically consider the concept of local economic development and tourism in the project of European integration as important segments of the overall progress of countries. The presented results, recommendations and defined conclusions will benefit the competent entities in the process of improving the state of local administration, tourism economy and integration into the European Union. Also, to other academic workers in further research on current topics. The economic development of local communities is based on the reorganization of business according to the principles of the new public management aimed at the real needs of the population. Tourist resources can be essential postulates of prosperity in all countries, including the Republic of Serbia. The starting hypothesis is that the concept of local economic development and tourism are important areas in the European integration project. At the same time, they mark areas with favorable opportunities for positive trends in society. By applying appropriate methodological procedures of analysis of available contents, synthesis and comparison, we will look at the first-class elements of our topic. The basis of the study is the available materials related to the functioning of local governments and tourism with realistic indicators in various domains of public life. The institutions of the European Union have conceived specific legal legislation in the given areas, as special regulations that are binding for members and countries in certain phases of accession. Our article deals with the improvement of local self-government through the implementation of proven modalities of economic development, where the application of modern management and reforms result in the improvement of the situation at the local level. Public administration needs to learn how to cooperate with local governments in order to gain more support in term of infrastructure investments while gaining more independence in the management of taxes from local touristic activities. Some of the common messages embedded in the abovementioned documents are very important for developing the approach and strategic foundation for sustainable tourism in Republic of Serbia. As it was stated sustainable tourism is positive approach intended to reduce the tensions and frictions created by the complex interactions between the tourism industry, visitors, the environment and the communities which are host to holidaymakers ...i.e., it is an approach which involves working for the long- term viability and quality of both natural and human resources. It can be concluded that the successful economic development of local administrations is ensured by applying modern paradigms of public management modeled on the systems of developed countries. Adequately profiled, tourism can be an essential area of the economy in the European integration project. Despite the obvious shortcomings, Serbia has certain comparative advantages and numerous resources important for its expansion. Geographical position, traffic infrastructure, natural resources, cultural heritage and other benefits indicate real possibilities for accelerated prosperity and successful entry into the community of developed countries. We are of the opinion that the leading state entities must eliminate the obvious weaknesses in the work of local administrations and incorporate the legal legislation of the European Union into their own legislation. It is necessary for the state leaders to pay more attention to the planned investments in tourism, hotel industry and processing industry. Implement the funds of the pre-accession funds of the European Union in fruitful development projects at the local level. Use the favorable strategic position with various natural resources and a healthy environment to promote the tourist economy with accompanying facilities. It is necessary to favor paradigms that motivate foreign investors, where business strategies are formulated based on established international principles. Implement current initiatives in cross-border cooperation projects of local communities and regions in accordance with the proclaimed national interests.
\end{abstract}

Key words: local economic development, tourism, resources, Serbia, European Union 


\section{INTRODUCTION}

The local economic development depends on the integration of the tourism sector with the whole economy. Tourism is forecast to double in size by 2030 as one of the fastest growing economies in the world - Serbia included. It is a key economic driver at national, state, territory and local levels throughout our country and the outlook is very promising.

From a strictly economic standpoint, "tourism is the second most important global sector, after financial services, and one of the fastest growing service industries for many economies in the world". (Alberti \& Giusti, 2012, p. 264) In line with this observation, Rogerson points out that "tourism is an evolving and dynamic activity that is easily adapted to social, political and economic changes. Its impact on the development of countries is evident, and that is why it has become one of the pillars of the world economy". (Rogerson, 2012, p. 154) To ratify these considerations, the World Tourism Organization (UNWTO), one of the main reference institutions in the sector, considers that the leisure industry represents, roughly, $10 \%$ of the gross world product; and, at the labor level, $9.6 \%$ of all jobs created.

Tourism activity is an important driver of the global economy, ensuring monetary circulation, through tourism receipts, to other economic circuits. By developing tourism activities, countries can increase their national production, with a positive effect on their Gross Domestic Product (GDP). Tourism services and cultural products should be promoted together in development efforts, as generators for regional progress in areas with partially valued heritage potential.

A strategic and integrated approach of sustainable cultural heritage tourism development must include all types of externalities, both positive and negative, and should be included in local policies for development as a priority, offering economically driven opportunities. Intensive development of tourism, which contributes to an increased added value, must be implemented in services through technology. Cultural heritage, promoted through tourism, creates jobs, drives innovation, supports public services development and local entrepreneurship (including transport and communication infrastructures), generates prosperity, and encourages participation of citizens.

Tourism is one of the world's largest and most dynamic forms of social and cultural exchange. It is also one of the largest forms of economic activity and a driver of economic development. While international visitor arrivals are predicted by the UN World Tourism Organization to reach 1,000 million within the next few years, domestic tourism is estimated to be more than five times that amount. Their research demonstrates that interest in the environment, culture and heritage is a primary motivation for more than $50 \%$ of travel, and is a consistently growing market area.

The contribution that tourism can make to poverty alleviation, to conservation of the natural and cultural heritage, and to overall sustainable development can be substantial. This is especially so in developing countries like Serbia, where natural resources and landscapes are still relatively untouched and where few other activities have a sustainable development potential, from an economic or environmental perspective. Furthermore, tourism has proved to be in many countries a much more sustainable development option that intensive agriculture, forestry, extractive mining or other primary activities.

Tourism has a major impact on local communities in tourist destinations. It can be a significant source of income and employment for local people. It can also pose a threat to the social fabric of an area and its natural and cultural heritage, which it depends on, but if it is well planned and managed it can be a force for their conservation. These stakes have led to a recognition of the tourism sectors need to incorporate the principles of sustainable development contained in Agenda 21, which was adopted at the Earth Summit in 1992.

The development of tourism in local communities is often an illustration of a community taking advantage of resources within community, which is an example of self-help approach to local economic development. The most prevalent approaches are: the self-help approaches to community development which is a strategy of community development in tourism development. The technical assistance approach to community development is based on technical information and expertise for improving the tourism in local communities. However, this approach has a downside and it can limit community capacity building. This is because governments use the technical approach to develop tourism and this can disempower local community and create dependency. (Begovic, Vacic, Matković \& Mijatović, 2016, p. 14) 
Some writers referred to technical assistance as a key element in building community capacity and increase skill (Rural Voices for Conservation Coalition, 2007). According to Pike, Rodriguez and Tomanev, the support of the government through a technical assistance can limit building capacity. Yet at the same time, government can also develop partnerships that foster community capacity building for tourism development. Thus, in third world countries particularly, without the government support, community capacity cannot be achieved.

The conflict approach stresses the equal distribution of resource in community and usually focuses on those with limited power. The idea of the conflict approach is to get people together to change a community. In this study, this approach has referred to decentralization in tourism organization and so it can refer to community participation in tourism development. In summary, community development literature is relevant to this study as it provides the rational and theoretical background for tourism development.

\section{MATERIALS AND METHODS}

Local economic development is a process of change in which the public and private sectors jointly recognize common problems in the economic environment, implement a policy and development plan that affect the reduction of problems and make the local community more competitive and the economy more powerful, thus improving the standard of living in the local community. Competitiveness is the most common driver of change. However, low entrepreneurial potential of local authorities and lack of financial resources are the most common obstacle. (Vasilijevic, 2012, p. 65)

Modern tendencies in local communities are that entrepreneurial management and activities of local authorities rely heavily on these partnerships, which appear in different areas of service delivery through the implementation of various arrangements and development projects. In the area of public service delivery, local authorities are given the opportunity to stimulate local initiative, increase local potential, attract investments and stimulate employment growth in their territory, and thus local economic development.

Local government is an important segment of the public sector when it comes to supporting economic development. Citizens expect local authorities to make efforts to tackle unemployment and raise quality of life. Economic development of local communities must be a priority, both for local government and central government. The most important goal, which proclaims the concept of local economic development, is to increase the number of employees in the territory of the local self-government unit. It can also be defined as an increase in the capacity of the local economy to create wealth for local residents, and therefore to improve their standard of living through increased employment, real wages, value of citizens' assets, etc.

Local economic development requires the development of new public management. It relies not only on the capacity of executive and governing bodies of government, but also on the partnership and close cooperation of organizations, institutions and individuals who contribute to the realization of public interests. There is probably no part of public administration that plays a more significant role in achieving "bono publico" as much as local economic development in practical application.

In the narrow sense, local economic development is understood as a strategic planning process through the partnership of local authorities, the private and non-governmental sectors, which, by focusing on stimulating investments, will ensure high and stable economic growth of local community. Each local economic development strategy is conceptualized based on the comparative advantages of the local community in relation to existing or potential markets. An additional objective of local economic development is to strengthen competitiveness, which in turn ensures sustainable development. There are two strategies for encouraging local development:

1. Attracting foreign firms to invest in the local community, through incentives given by local authorities to firms such as tax breaks and cheap land;

2. Encouragement of local groups by local authorities to develop their own businesses and thereby accelerate the economic development of the local community.

However, local economic development is not just about economic development seen in local contexts, as is often mistaken. The essence of local economic development lies in the collaboration of key local actors, partnerships with senior management, as well as a clear intention to effectively take advantage of the comparative advantages 
of a particular local community: economic and entrepreneurial potential, workforce structure, infrastructure network, geographical location and cultural historical specifics. It examines whether what benefits a country's entire economy can be applied for development purposes in a particular local community.

The concept of local economic development introduces competition, which is a starting point in economic reforms, from the macroeconomic level to the level of relations between the various political and territorial units that make up the state. (Neskovic, S., Djelic, T. A., Antonovic, R., Lutovac, M. \& Ketin, S., 2020, p. 4063)

Central government is an "indispensable" factor in stimulating local economic development, hence the partnership between local and republic authorities is often referred to as the "model of local development state". (Begovic, Vacic, Matković \& Mijatović, 2016, p. 75) The state adopts legislation, develops an organizational support network and establishes general development guidelines, which in contemporary economy is considered a precondition for the functioning of entrepreneurial administration.

The reform processes that changed the essence of the modern state in the late 1990s introduced a new concept of doing business into the socio-economic environment. These processes strongly affect local communities as important economic-political and service centers. By implementing comprehensive reforms of the welfare state, introducing modern governance, developing entrepreneurship, local government is taking an active role in stimulating local economic development, attracting foreign and domestic capital, increasing staffing and implementing public-private partnerships, with a perspective to solving problems and providing quality services to citizens and business.

The importance of entrepreneurial engagement of local authorities and the active participation of higher levels of government has been implanted into the practice of many local governments in the developed world, including Republic of Serbia. Implementation of business incubators, industrial and technological parks, free zones and various forms of public-private partnership are some of the elements of an entrepreneurial approach. An important segment is represented by the various forms of tax incentives and benefits provided by the local government or higher levels to the economy, as well as other projects by which the state provides funds to the local government to create an attractive environment for investors.

Local communities and central governments have developed a new partnership, which has led to an increase in the overall quality and scope of public services. Local authorities that have embraced the principles of entrepreneurial administration, investing their resources in modernizing management, professionalizing employed personnel, applying modern development methods, are becoming more efficient and competitive in providing services of adequate scope, high standard and quality, in short providing services that are tailored to the needs of citizens and business.

In market conditions, entrepreneurial local government should be most focused on attracting capital as a highly mobile resource. Capital easily moves from one local community to one that offers the most favorable conditions for business and profit making. That is why there is fierce competition between local authorities in attracting capital, but also other factors of production. Successful attraction of these factors enables the realization of the economic development strategy, that is, the establishment of sustainable economic development.

The key factor of entrepreneurship is innovation. With this in mind, the success of local governments in entrepreneurship is reflected in innovation in attracting investment. Entrepreneurial activity of the local government, within the framework of the local economic development strategy, is aimed at communication with investors, particularly owners of all factors of production. In addition, local authorities should develop and implement an effective public relations (PR) strategy to inform potential investors about the benefits of coming to their community. One of the crucial components is the creation and up-to-date maintenance of the website, with important local information available. In presenting the local community to the public, and especially to the target group of relevant individuals and businesses, entrepreneurship and innovation form an important segment of the “entrepreneurial spirit” of local government. (Begovic, Vacic, Matković \& Mijatović, 2016, p. 62)

The most important instruments of local economic development include public-private partnerships and concessions, business incubator centers, industrial, technology and science parks, various financial aid programs and funds, business and free zones, brownfield and greenfield investments. As an instrument of local economic development of particular importance, we should also mention the Local Economic Development Offices, which promote economic development in the local community in a professional and systematic way. Local governments 
most often recognize the need to strengthen their economic base when the problem of unemployment is intensified. At that point, usually the first line of thought is to do everything possible to attract a large investor or strategic partner. In this way, local economic development in Serbia has begun to boil down to a group of instruments whose main purpose is to attract foreign investors. It is often considered that if a municipality is "fortunate" with attracting one or two large investors, it has solved its biggest problems for the next ten or twenty years.

To address these issues facing local communities in our country, comprehensive cooperation and partnership between the local community, private and civilian sectors is necessary. In other words, not only local governments have an essential role in local economic development, but economic development is stimulated through active participation with other entities such as private companies, non-governmental organizations, central authorities, citizen advisory bodies and various foundations and financial institutions. The pragmatic benefit of local economic development is that through modern business ventures it is possible to increase employment and increase fiscal benefits. The basic meaning of local economic development is reflected in the effort to improve the quality of life in a particular local community.

\section{RESULTS}

Since the tourism industry operates in a global scale, the role of local public administration becomes more evident to be enough aggressive and aware of what they have to do in order to make their communities more and more involved in it and its revenues managed and invested in their local economies. They must learn how to match better local needs, demands and resources with global interest in local areas and communities.

At the same time, it is their responsibility to set up a stable infrastructure which in touristic terms is evidenced by public services offered, which benefit not only to local communities but at the same time support and in many cases reinforce the decision to tour of different tour operators and tourists. We can evidence more and more common initiatives of local governments involved in development projects and in partnerships with organizations operating in a global scale by helping local administration to gain competences necessary for the successful operation in supporting and managing the tourism sector.

Local economic development has become a global phenomenon. As we mention in previous chapter, this concept involves different activities, factors and participants and there is not a definition which may help to understand in synthesis what local economic development is. For the single territory, it is the challenge of enhancing prosperity and well-being. For a nation as a whole, a chance of development on a global scale starts from the local level. (Pedrana, 2013, p. 52)

Local economic development involves different strategies and issues, first of all, the relationship between private and public in the development of a local area. The institutional framework and rules and norms involved are essential for the good governance of local community. On the other hand, the local context and community and the partnership between private and public sector are essential for the development of all aspects and strategies involved.

Another cause of failure of traditional policies is the tendency to replicate standardized policies in different areas without a complete analysis of the local economic, social and institutional context. Moreover, traditional policies usually address to the promotion of specific industrial sectors, whereas local policies may address more to the development of networks and values chain in different sectors. Another aspect connected with local economic development is the territorial competition. Territories compete to attract investments, which may create competitive assets for the local development. Moreover, territories may compete to attract foreign companies in order to invest in the local production.

For the single enterprise, the territory may be considered as a resource, from which it gets inputs and skills for its activity. The area in which an enterprise is located is not just considered the location, but also a place where elements like institutions, social relations, capabilities and culture is deeply integrated.

The first studies on the impacts on territory by tourism were conducted in 1960s. They were about the spaces involved in tourism. For instance, Wilson and Clavé, analyze the relationship between space and tourism, through the difference between three regions, the departure, the transit and the arrival. (Wilson \& Clave, 2013, p. 165) 
Tourism is connected first of all with the accessibility of an area. In order to develop a tourist destination, transport systems and infrastructures help tourists in arriving to a destination. On this point, the role of public institutions and policies is crucial, in order to create the local structures and infrastructures to be accessible. Education and local skills, together with local culture and traditions, are often the element which attracts tourists to a destination. The tourism management has to be educated to receive people as tourists, with adequate skills. After the first tourists, the local industry tissue must be organized and created, in order to receive more tourists. Inward investments are essential for the development of an area.

Three are the main features in a tourism destination. First of all, the complexity of the local system of supply has to be analyzed. There are different enterprises with different purposes, which may not have the same concept of what the tourism destination is and how to improve it. The second important factor to be considered is the relationship with the territory. The main attraction for tourists is the natural environment, together with the social and cultural one. The third characteristic concerns with the seasonality and all economic, social and cultural problems.

The potential of a tourism destination is linked to the territory, especially in community tourism destination. The protection of the local context has to be the priority for the local government and local policies. Therefore, the potential policies of the local context have to be addressed to the sustainability, not only of the local economy, but also to the local natural and socio-cultural environment.

In tourism, the territory becomes the supply of the destination. Therefore, the use of the territory has to be in a sustainable view of the tourism in a destination. There are different effects of tourism on a destination. In figure 4 there are the positive and negative effects of tourism on the destination.

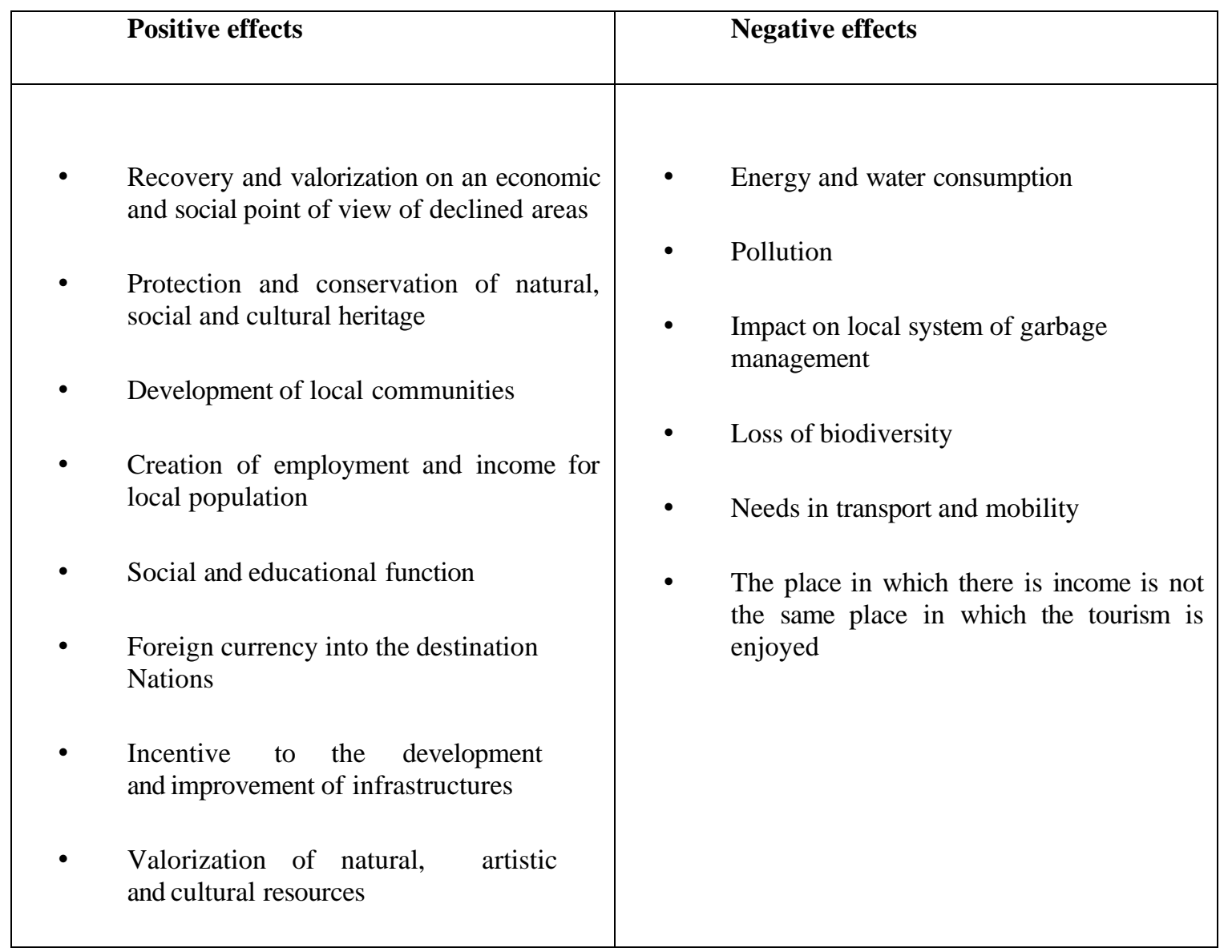

Figure 1. Possible effects of tourism on territory 
Source: Pedrana, M. (2013) Local economic development policies and tourism-An approach to sustainability and culture, Regional Science Inquiry Journal Vol. V, p. 97.

The positive effects are obviously connected with the local economic development of community. The increase in income and employment is the main positive effect of tourism on a defined area. A second important effect concerns the valorization of areas in which there had been industries and where they left from the area. Such areas may have high unemployment and risks connected with the decline of the area. Natural parks may attract tourists and therefore have the money for the protection of the natural resources. (Musaraj, 2016, p. 54)

However, there may be also negative effects. The first one is pollution and the deterioration of the environment. The natural, social and cultural environment may be deteriorated by the use of tourism, especially in the development phase, when mass tourists are coming to tourism destinations.

When we analyze general problems encountered by local human resources for the development of the touristic sector, probably under the influence of the globalization of the industry, they can be defined in similar ways, even if the touristic sector of a community is a consolidated one or if it is in the way to set up its infrastructure. This change in the chain of creation and provision of the touristic service creates from one side the increasing need for capabilities from international operators to deal with small localities features and from the other side the widening of origin countries of tourists makes necessary the immediate enlarge of capabilities of local operators to serve a multicultural client more demanding when it comes to the service standards.

These problems can generally be defined as lack of qualified staff both operational and managerial, failure in setting up and applying strategies of human development in a local level to support tourism development, lack of matching global needs from the touristic sector with the innovative capabilities of these localities.

Tourism studies curricula often create general profiles of operators or managers in the field of tourism as well as in administrating revenues from local touristic taxes. This evidences once again the need to establish a clear definition of the need to acquire capabilities which are a faster answer to the demands of the industry and the long run capacity building for local human resources to support the tourism sector and the area development which find a better solution in professional high schools and universities curricula.

\section{Discussions}

Natural values, cultural heritage and hospitality of people are among major appeals recognized by the strategic documents in Serbia and official statements of policy makers in the field of tourism. For the Government of Serbia, tourism is one of the priority areas in further socioeconomic development and also important for its reform within the process of accession to the EU. At the same time, the progress made towards EU integration during the last years provides important conditions and requirements for tourism development. In 2008,

Republic of Serbia signed the "Stabilization and Association Agreement" and in 2012, its candidate status was approved. Number of foreign tourists is increasing in Serbia, as well as the number of people travelling abroad, owning to the introduction of visa-free travel throughout EU countries for Serbian citizens.

At the national level, there is a Ministry of Trade, Tourism and Telecommunications of Republic of Serbia, and the National Tourism Organization of Serbia, dealing with promotion and market research of tourism, supporting implementation of the Tourism Strategy and tourism development. At the local level, there are municipalities and, in some cases, local tourist organizations, mainly funded by local authorities. The tourism planning and development, including human capacities and infrastructure, is under way mainly at the national level.

Being signatory of numerous global and EU conventions and agreements, Serbia has taken responsibility for their implementation in accordance with sustainability principles embedded in each of the documents. Starting from the globally accepted Millennium Development Goals, through the Convention on Biological Diversity with its Guidelines on Biodiversity and Tourism developed in 2004, Serbian policy and approach in developing sustainable tourism is under unavoidable implications of the broad set of documents, adopted at the national level over. Receiving the status of EU candidate country, Serbia is to comply with principles and directions developed by the EU over the past decade. The European Union Strategy for Sustainable Development (EU SDS), developed 
by the European Council, adopted in 2001 and revised in 2006 and 2009 is an umbrella document. Specific guidelines for the policy development and practice towards sustainability and EU integration are suggested by the most relevant documents for sustainable tourism developed at the European level, such as the Declaration on Ecotourism (2002), Declaration on Climate Change and Tourism (Davos Declaration), as well as the Agenda for a Sustainable and Competitive European Tourism (2007).

Since the Instrument for Pre-accession Assistance (IPA) is one of the main funding mechanisms of the EU for the accession countries, it is important to consider its Strategic Coherence Framework (SCF) document, setting Serbia's economic, social and environmental development goals. It emphasizes the importance of the environment in tourism development in terms of protection of natural values, but also in terms of improving the waste and water management and environmental services crucial for both economic development and societal well-being, and their sustainability.

Implementing the policy and projects in Serbia today and in the future needs a significant support, both technical and financial, to tourism, as well as to other fields of development. Therefore, it is very important to consider the European Principles for the Environment (EPE) as an initiative of the five signatory European-based Multilateral Financing Institutions (MFIs): Council of Europe Development Bank (CEB), European Bank for Reconstruction and Development (EBRD), European Investment Bank (EIB), Nordic Environment Finance Corporation (NEFCO) and Nordic Investment Bank (NIB). It is founded on their commitment to promote and ensure sustainable development and environmental principles, practices and standards associated with financing the projects.

For projects located in the Member States of the EU, the European Economic Area countries, the EU Acceding, Accession, Candidate and potential Candidate Countries, the EU approach, which is defined in the EC Treaty and the relevant secondary legislation is the logical and mandatory reference. The projects in this region should also comply with any obligation and standards upheld in relevant Multilateral Environmental Agreements. Since one of them, the European Bank for Reconstruction and Development (EBRD) is present in Serbia providing funds for projects in different fields, including tourism, it is of particular interest for policy makers and implementers to understand, respect and comply with the principles they incorporate into its Social and Environmental Policyranking the financing of sustainable development projects among the highest priorities. The Bank has defined a set of specific Performance Requirements ("PR's") that clients are expected to meet, covering key areas of environmental and social impacts and issues. Under each of the PR's, there are objectives, scope and specific steps and activities described in order to provide clear guidance for project holders and stakeholders.

The most relevant strategies and legislation in the field of tourism in Serbia have been developed and adopted over the last ten years, supported by foreign technical and financial aid. However, as it was stated, the "plan implementation is still at the low level, and aspects of economic development in trans- border cooperation are insufficiently promoted". The Tourism Development Strategy of the Republic of Serbia was adopted in 2016. The Project aimed at the Support to Implementation of the strategy for tourism (2016-2025), funded by EU and performed in close cooperation with the Ministry of Trade, Tourism and Telecommunications as the main beneficiary, resulted in recommendations for updating “... the Strategy related policies in line with best EU practice".

From the perspective of cross sector approach and sustainability principles, the Strategy needs significant improvements. Sustainable development principles are not clearly present as guidelines and the foundation of the Tourism Development Strategy of Serbia. While natural values and protected areas are seen as important resources for tourism development, and its integrated management as one of the preconditions for its sustainability, it is not recognized as one of the key elements of tourism product branding. The expansion of protected area over the territory of Serbia may be considered as one of the measures of its biodiversity protection, and that is the only, indirect, link found in the Strategy between biodiversity and tourism development.

Involving of local community in planning, decision making and implementing of activities has been largely embedded in relevant international documents and requirements of EU policy. In Serbia, as in many other countries, this is reflected in all the documents regulating environmental and tourism sectors, including planning procedures. The Law on Free Access to Information of Public Importance, provides the platform for public participation relevant in many aspects for tourism development. 
The Law on Environmental Protection, as well as specific laws pertaining to the Strategic Environmental Assessment (Law on Strategic Environmental Assessment, RS Official Gazette Nos 135/04, 36/09, 43/11 and 14/16) and those covering planning procedures, bring to Serbian society new opportunities to be informed and involved in decision making on issues relevant for their everyday life, and to government institutions and project holders new, sometimes complex, responsibilities. In planning, as defined by Article 13 of the Law on Tourism, the Strategic Master Plan is a crucial document for "drafting spatial and urban plans at the priority tourist destinations and tourism areas" as these plans shall establish "conditions for the construction of tourism infrastructure facilities". However, it should be stated that the Law on Planning and Construction (Official Gazette of RS Nos. 72/2009, 81/2009 - correction, 64/2010 - decision of the CC, 24/2011, 121/2012, 42/2013 - decision of the CC, 50/2013 - decision of the CC, 98/2013 - decision of the CC, 132/2014, 145/2014, 83/2018, 31/2019 and 37/2019 - other act does not oblige the developer of the Plan to cooperate with the local community and civil society who live in the vicinity. (Petovar \& Jokic, 2017, p. 7) Also, one of the limitations for public participation in decision making in Serbia is a lack of experience and knowledge about techniques and methods, as well as insufficiently developed mechanisms and procedures for public participation in decision making.

However, it should be stated that in recent years initiatives have been taken to mobilize public awareness of various programs and actions for protecting the environment and implementing sustainable development strategies such as the Local Environmental Action Plans (LEAP) and Local Agendas (LA21). For these, strong support of local authorities and population has been reported, together with that of foreign donors. In strategies for tourism, rural tourism and natural resources development, there is a general awareness of community issues and their rights to public participation. There is a common understanding on the needs of the public to be informed and involved in the development. However, this is interpreted mainly as being confined to levels of information and consultation rather than to specific instruments and mechanisms of participation on an equal basis. In the documents in both sectors, the focus on "stakeholders", "public", local authorities or NGO (non-profitable) sector, is much stronger than on local communities and specifically targeted groups. Local community issues are directly incorporated into, and elaborated in the most successful manner within, the Draft National Strategy of Sustainable Use of Natural Resources and Goods and in the Draft Sustainable Rural Tourism Development Strategy. There is a general respect for local culture, but not directly related to the promotion of traditional knowledge in sustainable development and use of resources, or local communities sharing in economic and other benefits of tourism.

\section{Conclusions}

In a local economic development perspective, the interaction between tourism and community becomes fundamental. Tourism has become one of the most important industries. It is based on globalization and its role in the global development, whereas its dimension is local and it is connected with the local tissue of enterprises. Starting from a model of local economic development, institutions have to be aware of the problems and risks of a not well organized and sustainable program of intervention on the territory. Government intervention has to declare routes for the local economic development, especially for what concerns sustainability.

What characterizes local economic development in Serbia is an underdeveloped entrepreneurial culture, modest infrastructure that has not been invested in for years, insufficient financial capacity of local governments, inefficiency of local administrators, but also non-application of laws, by-laws and regulations that apply to the area of local development and high levels of corruption. Additional problems include: large number of fiscal and parafiscal charges, insufficient practical implementation of strategic documents in the field of economic development, underdeveloped institutional forms of local economic development offices, unresolved issues of local ownership and the non-use of bonds and securities by local authorities and incipient economic development instruments that have experienced enviable expansion in the modern world.

In order to achieve the goals of local economic development in an optimal way, it is necessary to respect the principles of depoliticization, professionalization, modernization and innovation when implementing the reforms of local administrative bodies. In countries where the quality of work of public authorities is relatively low, the quality of work of local administrations is generally even lower. The reform of the local administration in the cities, towns and municipalities in our country will ensure the efficiency of the public service system, reduction of costs and greater accessibility and quality of public services in tourism. Tourism is considered today a global industry, perhaps the largest in the world. At the same time its impacts and benefits are becoming more and more local, as more local is becoming the management of the revenues from its operation. 
Up to day, other activities which previously used to be included to other sectors of the economy, actually are being integrated in the operational chain of the touristic products and services by changing the way they are managed by getting closer to the final consumer. This creates a new local environment since it creates new perceptions and behaviors from both sides: operators and clients, local communities are more and more included in this chain in the role of providers, labor force and administrators. Local self-government creates a new local economy by playing a multiple role in it. Local communities learn not simply to evidence and use local natural and historical resources for their direct benefits, but also, they learn to evidence and promote the way of living, thinking and feeling as unique touristic offers by enlarging and transforming the product and service more root-based.

Tourism stakeholders must plan effectively now and be ready to adapt to change to leverage the opportunities that are said to arise. Local self-government is at the forefront of tourism delivery and in many ways the linchpin to other spheres of government, industry and the community. It provides an expanse of tourism infrastructure, from roads, to airports, ski centers, and parks just to name a few. Local Government in a tourism setting is governed by legislation from the State, from land-use planning through to environmental and health legislation; it is impacted by national tourism strategies, as well as other government strategies, and participates in, and contributes to the activities of tourism organizations and networks. Industry that supports tourism - accommodation, retail, restaurants, bars and cafes, all have reciprocal relationships with, and of course exist within local administration jurisdictions.

Local communities in various aspects of their economic development and management of tourism businesses need skills to provide better opportunities of employment in the tourism and hospitality sector. Under this optics, training institutions, professional center and universities must set up customer tailored study curricula to build up highly qualified and well-trained human resources in the public and private sectors. This to provide qualified human resources to develop, manage and serve the industry in a sustainable and competitive manner in accordance with international standards.

All this attempt will contribute the spirit of solidarity and support between operators at a local level, facilitate a better integration of the local touristic activity in a global scale, provide a better utilization of the revenues from tourism to improve local infrastructure and improve the economic performance of the region. The legal framework in different areas which in many cases in being restricted by agreements and geopolitics, the overall level of advancement in capacities and practices of local administrations, the level of integration of the touristic sector with the global industry, local features which imply specific behaviors and trends from operators and tourists in the area, interact and the outcome defines ways in which the sector can better serve as a real leverage to the sustainable local social and economic development.

In conclusion, we would like to emphasize the fact that decision regarding the improvement of effectiveness and efficiency of the touristic sector by improving the collection and management of local touristic tax, does not depend simply in the goodwill of local governors. 
ISSN 2661-2666 (Online) International Scientific Journal Monte (ISJM) DOI: 10.33807/monte.202004650

Volume 3 No. 1 (2020): April

\section{REFERENCES}

Alberti, F. G., \& Giusti, J. D. (2012) Cultural heritage, tourism and regional competitiveness: The Motor Valley Cluster, City, Culture and Society vol. 3.

Begović, B., Vacić, Z., Matković, G. \& Mijatović, B. (2016) Local economic development, Belgrade: Centre for liberal-democratic studies and Standing Conference of Towns and Municipalities.

Brooks, G. (2011) Heritage as a driver for development, ICOMOS Paris 2011.

Musaraj, A. (2016) Tourism development, touristic local taxes and local human resources, Enterpreneurship Training Center Albania.

Neskovic, S., Djelic, T. A., Antonovic, R., Lutovac, M. \& Ketin, S. (2020) Incorporation of Information Communication Technologies in Economic and Environmental Espionage, Fresenius Environmental Bulletin - FEB, Volume 29 - No 05/2020.

Pedrana, M. (2013) Local economic development policies and tourism-An approach to sustainability and culture, Regional Science Inquiry Journal Vol. V.

Petovar, K. \& Jokić, V. (2017) The right of servitude between public interest and undisturbed use of private property, SPATIUM International Review.

Rogerson, C., M. (2016) Tourism-LED local economic development: The South African Experience, Urban Forum.

Vasiljević, D. (2012) Local Economic Development, Belgrade: PALGO Center.

Wilson, J. \& Clavé, S., A. (2016) Geographies of Tourism: Europe Research Perspectives, Tourism Social Science Volume 19, Emerald. 